\title{
Determinants of Agricultural Output in Nigeria
}

\author{
${ }^{1}$ OMEKWE, Sunday Omiekuma Paul, ${ }^{2}$ BOSCO,ItoroEkpenyong, ${ }^{3}$ OBAYORI, Joseph Bidemi \\ ${ }^{I}$ Department of Economics, Faculty of Social Sciences University of Port Harcourt, Nigeria \\ ${ }^{2}$ Department of Economics, Faculty of Social Sciences University of Port Harcourt, Nigeria \\ ${ }^{3}$ Department of Economics, Faculty of Social Sciences, NnamdiAzikiwe University Awka, Nigeria.
}

\begin{abstract}
The study examined the determinants of agricultural output in Nigeria from 1985-2016. It employs the econometric techniques of co-integration test and ECM approach to analyze the data obtained from the CBN statistical bulletin. The Augumented Dickey Fuller unit root test results showed that all the variables were stationary at first difference. The Johansen co-integration test results showed that co-integrating equations exist which fit the model for the ECM. Meanwhile, the ECM results showed that; government funding in agriculture is positively and significantly related to agricultural output, agriculture credit has positive and significant impact on agricultural output. Also, climate change has a positive and significant effect on agricultural output. The findings from the study showed that agricultural funding; agricultural credits as well as climate change are key determinants of agricultural output in Nigeria. Based on these findings, the study recommends amongst others that there should be increase infrastructural funding in the yearly budget in order to provide infrastructural facilities to the rural areas where bulk of farm products are produced. Also, credit to the agricultural sector via the rural farmers should be encouraged.
\end{abstract}

KEY WORDS: Determinants, Agricultural Output, Credit, Funding, Climate Change

\section{INTRODUCTION}

Prior to the attainment of political independent in Nigeria, the country's economy is agrarian in nature, which implies that agriculture is not only the core industry but the backbone of Nigeria economy. The agricultural sector has a multiplier effect on any nation's socio-economic and industrial fabric because of the multifunctional nature of agriculture (Obi \&Obayori, 2016). For instance, record shows that the then revolutionary free education programme in the western region was funded entirely from cocoa, rubber and palm oil proceeds. Also Ahmadu Bellow University (ABU), Zaria and University of Nigeria, Nsukka, (UNN), were built from the proceeds from cotton, groundnuts, rubber and palm oil. But the oil boom of the 1970s created relative disincentives for agriculture in relation to other sectors of the economy resulting in the increased dependence on a mono-cultural economy based on oil.

Some of the main factors undermining agricultural production include climate change, inadequate budget to agricultural sector and low productivity due to poor planting material amongst others. In addition, the decline in food production which has led to increasing food importation in Nigeria can be likened to farmer's difficulty to obtain fertilizer and patching access to credit. Consequently, food production profile in Nigeria has been at lower ebb. This lead to a rise in import of stable foodper annum(Anigbogu, Abosi\&Okoli, 2015).

According to Polycarp and Jirgi, (2011), even though,agriculturecontribute $42 \%$ of the GDP, provides employment and a means of livelihood for more than $60 \%$ of the productivity engaged population, it receives less than $10 \%$ of the annual budgetary allocation, Thus, under funding in this regard is central to decline in agricultural output 
inNigeria.As a follow up, the Nigerian Agricultural Development and Cooperative Bank Limited, which is meant to provide credit facilities to farmers, have its major challenges in effective delivery of' its duties (Ukeje, 2010).

According to Hoffmann (2013) climate change and agriculture are interrelated processes, both of which take place on a global scale. Climate change affects agriculture in a number of ways, including through changes in average temperatures, rainfall, climate; the nutritional quality of some foods and changes in sea level. The effect of climate change on agriculture is unevenly distributed across Nigeria and it negatively affects crop production in low latitude regions, while the effects in northern latitudes may be positive or negative. Similarly, since Nigeria lies between latitudes $4^{\circ} \mathrm{N}$ and $14^{\circ} \mathrm{N}$ of the equator, Nigeria's temperatures are usually in the $30^{\circ} \mathrm{c}$ all year round, high humidity in the south and the amount of rainfall along the coast is high (generally between 2,000-3,000mm), with some eastern areas receiving over $4,000 \mathrm{~mm}$.

According to Nworgu (2006) successive governments over the decades, initiated numerous policies and intervention strategies such as; National Accelerated Food Production Programme (NAFPP), Agricultural Development Project (ADP), Operation Feed the Nation (OFN), Agricultural Credit Guarantee Scheme Fund (ACGSF) to restore the agricultural sector in Nigeria to its pride of place in the economy. Also, to minimize sharp practices, Government introduced the electronic wallet system, which allows farmers to receive subsidized electronic vouchers for their seeds and fertilizers (Ikeh, 2013).

Despite successive governments' huge investments and various strategies of intervention in the agricultural sector, agricultural production output looks precarious. This is because the basic determinants of agricultural production such as climate change, government funding, favourable government monetary policy vis-à-vis low interest rate on agricultural loanhave not been given adequate attention in order to boost agricultural production (Obi \&Obayori, 2016). Similarly, the utter neglect of agriculture and overdependence on oil had created disincentives to millions of farmers who had abandoned their farming implements and migrated into cities in search of jobs outside the farms. This has resulted to sharp decline in agricultural production output. Thus, the objectives of this study were to; examine the impact of government funding agriculture on agricultural output in Nigeria;access the impact of agricultural credit on agricultural production output in Nigeria; and examine the impact of climate change on agricultural production output in Nigeria.

\section{REVIEW OF RELATED LITERATURE}

\section{Theoretical Framework}

The theoretical background of this study is rooted in the Cobb Douglass production function that provides a useful basis for analyzing productivity drivers. It may be represented algebraically or diagrammatically. As expected, it is a relationship between what goes into a production process (inputs) and what comes out (output). Therefore, output is a function of inputs of labour, capital and improvement in technology. This theoretical model has been applied in extant literature. It starts with the idea of production functions, namely, that the quality of output $(\mathrm{Q})$ in any sector is a function of the amounts and quantities of inputs or factors of production.

In economics, the Cobb-Douglas functional form of production functions is widely used to represent the relationship of an output and two inputs. Cobb- Douglass considered a simplified view of the economy in which production output is determined by the amount of labour involved and the amount of capital invested. While there are many other factors affecting economic performance, their model proved to be remarkably accurate (Anigbogu, Abosi\&Okoli, 2015).

The function they used to model production was of the form; $P(L, K)=B L^{\alpha} K^{\beta}$.

Where: $\mathrm{P}=$ total production (the monetary value of all goods produced in a year), $\mathrm{L}=$ labor input (the total number of person-hours worked in a year), $\mathrm{K}=$ capital input (the monetary worth of all machinery, equipment, and buildings), $\mathrm{B}=$ total factor productivity(efficiency coefficient) $\alpha$ and $\beta$ are the output elasticity of labor and capital, respectively. These values are constants determined by available technology. 
In this production function, the sum of exponent $(\alpha+\beta)$ measures returns to scale.

Output elasticity measures the responsiveness of output to a change in levels of either labour or capital used in production, Ceteris Paribus.

The primary purpose of the production function is to address allocative efficiency in the use of factors inputs in production and the resulting distribution of income to those factors, while abstracting away for the technological problems of achieving technical efficiency, as an engineer or professional manager might understand it.Similarly, in agricultural production, efficient allocation of agricultural inputs helps farmers to attain their desired objectives. It avails farmers the opportunity of improving their productivity and income. At the micro-economic level efficient allocation of agricultural resources (farmland, credit facilities, fertilizers, seedlings, labour among others) help farmers to contribute to food production, employment generation, industrial raw material and export product for foreign exchange earnings.

\section{Empirical Framework}

Eminent scholars over the past yearshave explained the determinants of agricultural output in both developed and emerging economies. Some of those empirical works include; Odhiambo, Nyangito and Nzuma (2004) used OLS to examine the sources and determinants of agricultural growth and productivity in Kenya from 1965-2001. The results showed that labour, land, trade policy, climate and government expenditure on agriculture are important determinants of agricultural productivity. That is, labour, land, trade policy, climate and government expenditure on agriculture significantly impact on agricultural productivity.

Oyekale (2007) used Error Correction Modeling to examine the determinants of agricultural land expansion in Nigeria. The estimated result using ADF test showed that all the variables were stationary and there were seven cointegration vectors using Johansen co-integration test. The dynamic unrestricted short run parameters of permanent cropland growth rates, agricultural production index, livestock population, human population, cereal cropland growth rate and other land have significant impact on agricultural land expansion.

Ahmad and Heng (2012) used ARDL to examine the determinants of agriculture productivity growth in Pakistan from 1965-2009. The results showed that fertilizer is the most determinant with long run and short run elasticities of 0.16 and 0.2 respectively. This verifies that the impact of fertilizer on total factor productivity is subject to diminishing return. Human capital is the next important determinant with long run and short run elasticities of 0.14 and 0.09 respectively. This indicates that return to school education of farmers is increasing and the experience gained help to improve agricultural productivity. Agricultural credit has a relatively lower long run and negative short run elasticities of 0.1 and -0.03 respectively. Area under crop cultivation is insignificant with long run and short run elasticities of -0.42 and 0.27 respectively. The speed of adjustment of the model is $65 \%$, meaning that the model is stable.

Oluwatoyese and Applanaidu (2014) used the OLS to examine the effect of agricultural sector determinants on economic growth in Nigeria from 1981-2011. The results showed that fishery, food production, forestry and livestock have positive relationship with economic growth. While fishery and food production has significant impact on economic growth, forestry and livestock has insignificant impact on economic growth.

Adeyemo (2015) examined the determinants of palm oil production in Nigeria from 1971-2010 with the methods of co-integration and ECM. The study used secondary data on palm oil output as the dependent variable, while, palm oil price, real exchange rate, crude oil price and structural adjustment programme are the independent variables. The results showed that the variable were stationary at order one and co-integrated. Also, the ECM result showed that the speed of adjustment is $99.8 \%$. The coefficient of palm oil price and SAP is negatively related to palm oil output, while that of exchange rate and crude oil price is positively related to palm oil output.

Udah, Nwachukwu, Nwosu, Mbanasor and Akpan (2015) examined the determinants of agricultural export growth in Nigeria from 1960-2010 with the used of Ordinary Least Square regression analysis. The estimated results showed that growth in market price of agriculture export, growth in trading partner, growth in exchange rate, growth (C) 2018, IJSMS 
in agricultural export intensity and government expenditure in agriculture all have positive relationship with agricultural export growth. While both growth in interest rate and growth in infrastructural development had negative relationship with agricultural export growth.

Udah and Nwachukwu (2015) examined the determinants of agricultural GDP growth in Nigeria. The study used time series data and applied the method of OLS. The result showed that agricultural labour, infrastructural development and total factor productivity had positive relationship with agricultural GDP. While, agricultural land, inflation rate were negatively related to agricultural GDP.

Meanwhile, the study shares the view that agricultural sector has the greatest potential to free the country from its heavy dependence on oil wealth. The study is justified on the need to encourage inclusive development in agricultural sector with the intention to permit relevant ministries, stakeholders and non-governmental organizations (NGOs) to participate in rejuvenating agriculture.

To achieve this noble ambition, secondary data were collected on agricultural production output, government funding to agricultural production, agricultural credit and climate change. Also, the econometrics method of Unit root test, co-integration and ECM test were applied on the collected data in order to test for the relationship between the variables under consideration.

\section{RESEARCH METHODOLOGY}

The nature of this research work requires employing quantitative techniques of analysis. The study uses time series data from secondary sources. The data required are sourced through Central Bank of Nigeria bulletin and National Bureau of Statistics bulletin,

\section{Estimation Techniques}

A descriptive statistic for all the variables was first carried out.. The study also conducts a stationarity test of each variable by employing the augmented Dickey-Fuller (Dickey and Fuller, 1979) unit root test in order to avoid any spurious regression. Next, a system-wise Johansen co-integration test (Johansen, 1988; Johansen and Juselius, 1990) was used to analyze the presence of the long-run equilibrium relationship among the variables under study. The use of Johansen co-integration was premised on the fact that the variables were integrated at order one 1(1). The presence of co-integration makes an error correction mechanism (ECM) model more applicable.The purpose of the ECM is to indicate the speed of adjustment from the short-run equilibrium to the long-run equilibrium state.

\section{Model Specification}

Thedeterminant of agricultural output is expressed as;

$\mathrm{Y}=\mathrm{f}\left(\mathrm{X}_{1}, \mathrm{X}_{2}, \mathrm{X}_{3}\right)$

$\mathrm{Y}=\alpha_{\mathrm{o}}+\alpha_{1} \mathrm{X}_{1 \mathrm{t}}+\alpha_{2} \mathrm{X}_{2 \mathrm{t}}+\alpha_{3} \mathrm{X}_{3 \mathrm{t}}+\mu$

The model in equation (2) is further restated in the log-linear form. This is aimed at reducing the problem of multicollinearity among the variables in the model and as well estimates the variables in the same unit of measurement. Thus, the log-linear model is specified as shown below;

$\ln Y=\ln \alpha_{0}+\ln \alpha_{1} X_{1 t}+\ln \alpha_{2} X_{2 t}+\ln \alpha_{3} X_{3 t}+\mu$

Equation (3) was transformed in an error correction as follows:

$\mathrm{Q}_{\mathrm{t}}=\alpha_{0}++\Sigma \alpha \mathrm{Q}_{\mathrm{t}-1} \Sigma \alpha_{1 \mathrm{t}} \mathrm{X}_{\mathrm{t}-1}+\Sigma \alpha_{2 \mathrm{t}} \mathrm{Y}_{\mathrm{t}-1}+\Sigma \alpha_{3 \mathrm{t}-1} \mathrm{Z}_{1}+\delta_{1} \mathrm{ECM} \mathrm{t}_{\mathrm{t}-1}+\mathrm{U}_{\mathrm{t}}$

Where: $Y=$ Agricultural Output, $X_{1}=$ Government Funding in Agricultural Sector, $X_{2}=$ Agricultural Credit, $X_{3}=$ Climate Change, $\mu=$ stochastic random variable, $\mathrm{Ln}=$ the logarithmic transformation to the natural base, $\alpha_{0}=$ intercept parameter, $\alpha_{1-} \alpha_{3}=$ slope parameter, $\mathrm{t}=$ Time/Period

Apriori Expectation; $\alpha_{1}>0, \alpha_{2}>0$ and $\alpha_{3}>0$ 


\section{RESULT PRESENTATION AND DISCUSSION OF FINDINGS}

\section{Table 1: Descriptive Statistics of Variables}

\begin{tabular}{|l|c|c|c|c|}
\hline VARIABLE & $\mathrm{Y}$ & $\mathrm{X}_{1}$ & $\mathrm{X}_{2}$ & $\mathrm{X}_{3}$ \\
\hline Mean & 214390.0 & 23896.90 & 29811.36 & 92.86730 \\
\hline Median & 108814.1 & 10596.40 & 22454.00 & 92.83000 \\
\hline Std. Dev. & 307162.5 & 25256.05 & 39635.02 & 8.576901 \\
\hline Skewness & 4.630114 & 0.659883 & 4.402486 & -0.310602 \\
\hline Jarque-Bera & 948.4328 & 3.427346 & 841.5796 & 0.610101 \\
\hline Prob & 0.000000 & 0.180203 & 0.000000 & 0.737086 \\
\hline
\end{tabular}

Source: Researcher's Computation from E-view Result in the Appendix II

Note: $\boldsymbol{Y}$ stands for Agricultural Output; $\boldsymbol{X}_{1}$ stands for Government funding in agricultural sector; $\boldsymbol{X}_{2}$ stands Agricultural Credit and $X_{3}$ stands for Climate Change

The descriptive statistics reported in Table 1 indicated that agricultural output (Y), government funding in agricultural sector (X1), credit to agriculture (X2) and climate change (X3) averaged 214390.0million, $\$ 23896.90$, $\$ 29811.36$ million and $92.8673 \mathrm{~mm}$ respectively. The skewness test result showed positive values for all the series except climate change that has negative value. The positive value skewness means that the variables have high tails. The probability of Jarque-Bera statistics suggest that the null hypothesis of normal distribution for government funding on agriculture and climate change are rejected at 5\% level while that of the variables agricultural output and agricultural credit cannot be rejected.

Table 2: ADF Unit Root Test at Level

\begin{tabular}{|l|c|c|c|c|c|}
\hline \multirow{2}{*}{ Variables } & ADF Test & \multicolumn{3}{|c|}{ Critical Value } & \multirow{2}{*}{ Decision } \\
\cline { 2 - 6 } & & $\mathbf{1 \%}$ value & $\mathbf{5 \%}$ value & 10\% value & Non-Stationary \\
\hline $\mathrm{Y}$ & -1.96628 & -3.63290 & -2.94840 & -2.61287 & Non-Stationary \\
\hline $\mathrm{X}_{1}$ & -0.59236 & -3.63940 & -2.95110 & -2.61930 & Non-Stationary \\
\hline $\mathrm{X}_{2}$ & -2.86171 & -3.62678 & -2.94584 & -2.61153 & Non-Stationary \\
\hline $\mathrm{X}_{3}$ & -0.54428 & -2.63268 & -1.95068 & -1.61105 & \\
\hline
\end{tabular}

Source: Researcher's Computation from (E- view 9.0)

The results presented in Tables 2 depicted that noneof the variables was at level. Thus, a first difference operation was conducted on the series in the next table.

Table 3: ADF Unit Root Test at First Difference

\begin{tabular}{|l|l|l|l|l|l|}
\hline \multirow{2}{*}{ Variables } & ADF Test & \multicolumn{2}{|c|}{ Critical Value } & \multirow{2}{*}{ Decision } \\
\cline { 2 - 6 } & & $\mathbf{1 \%}$ & $\mathbf{5 \%}$ & -2.61287 & Stationary \\
\hline $\mathrm{Y}$ & $-10.1428^{*}$ & -3.63290 & -2.94840 & -2.61430 & Stationary \\
\hline $\mathrm{X}_{1}$ & $-9.98809^{*}$ & -3.63940 & -2.95112 & -2.61430 & Stationary \\
\hline $\mathrm{X}_{2}$ & $-5.95804^{*}$ & -3.63940 & -2.95112 & -1.61105 & Stationary \\
\hline $\mathrm{X}_{3}$ & $-11.0345^{*}$ & -2.63268 & -1.95068 & & \\
\hline
\end{tabular}

Source: Researcher's Computation from (E-view 9.0) Result in the Appendix II 
Since the results presented in Tables 2 showed that noneof the variables was at level, the variables were differenced once in Table 3 and became stationary at first difference prior to subsequent estimations to forestall spurious regressions. Hence, the entire variables in this study are stationary. This therefore means that the best regression results were obtained when the above variables are used for model estimation.

Table 4: Johansen Co-integration Result

\begin{tabular}{|c|c|c|c|c|c|}
\hline $\begin{array}{l}\text { Trace Statistics) } \\
\mathrm{k}=3, \mathrm{r}=3\end{array}$ & $\begin{array}{l}\text { Critical Values (5 } \\
\%)\end{array}$ & Prob & $\begin{array}{l}\text { (Max-Eigen } \\
\text { Statistics) } k=3, r=2\end{array}$ & $\begin{array}{l}\text { Critical Values } \\
(5 \%)\end{array}$ & Prob \\
\hline $173.2714^{*}$ & 69.81889 & 0.0000 & $110.6751 *$ & 33.87687 & 0.0000 \\
\hline $62.59636 *$ & 47.85613 & 0.0012 & $29.58351 *$ & 27.58434 & 0.0273 \\
\hline $33.01284 *$ & 29.79707 & 0.0206 & 18.29524 & 21.13162 & 0.1192 \\
\hline 5.551830 & 3.841466 & 0.0185 & 5.551830 & 3.841466 & 0.0185 \\
\hline
\end{tabular}

Source: Researcher's Computation from (E-view 9.0) Result in the Appendix II

Note: $r$ represents number of cointegrating vectors and $k$ represents the number of lags in model.

The test statistics indicated that the hypothesis of no co-integration, $\mathrm{H}_{0}$, among the variables can be rejected. The results of both Trace and Max-Eigen statistics revealed that three and two co-integrating vectors respectively among the variables in the model. Based on these findings, it is concluded that the variables have long run relationship. This therefore necessitated the estimation of co-integration regression model to reflect the long run behaviour of the regressors (explanatory variables).

Table 5Estimation of Long Run Co-integration Regression Result

\begin{tabular}{|c|r|r|r|r|}
\hline Variables & Coefficient & T-Statistics & T-Table & Probability \\
\hline $\mathrm{X} 1$ & 2.164219 & 1.912357 & & 0.0728 \\
\hline $\mathrm{X} 2$ & 7.422327 & 6.408878 & & 0.0000 \\
\hline $\mathrm{X} 3$ & -10888.04 & -2.912062 & & 0.0097 \\
\hline $\mathrm{C}$ & 972049.8 & 2.869378 & & 0.0106 \\
\hline $\mathrm{R}^{2}=0.9693$ & \multicolumn{2}{|l}{ DW-Stat $=2.027012$} & F-stat $=26.20779$, F-prob $(0.0000)$ \\
\hline
\end{tabular}

Source: Researcher's Computation from (E- view 9)

The co-integrating regression model which measures the long run behaviour of the explanatory variables was conducted using the Dynamic Least Squares (DOLS)and the result is reported above. The estimated co-integration regression result of the GDP model in Table 5 showed that the coefficient of determination is $97 \%$. This shows that the independent variable in the resgression model jointly explained 98 percent of the systematic variation agricultural production output. Meaning that the regression has high explanatory power, and by extension, the estimated model is a good fit. Also, the coefficient of all the explanatory variables has the hypothesized signed positive sign for (XI and X2) and negative sign for (X3). Also, the explanatory variables (X2 and X3) were statistically significant at 5\% level while (X1) was insignificant. The Wald test for coefficient restrictions indicated that the independent variables are jointly significant in explaining variation of the dependent variable. This further attests to the overall significance of the entire model at the convectional 5 percent level. The Durbin Watson statistics value of 2.0 revealed that the model is not serially correlated at 5 percent level, this attests to its reliability for long term prediction. 
Table 6: Parsimonious Error Correction Mechanism

\begin{tabular}{|c|r|r|r|r|}
\hline Variables & \multicolumn{1}{|l|}{ Coefficient } & \multicolumn{1}{l|}{ T-Stat } & \multicolumn{1}{l|}{ T-Table } & Prob \\
\hline $\mathrm{C}$ & -0.036123 & -0.418127 & 2.0369 & 0.6796 \\
\hline DLOG(Y(-1)) & 0.574063 & 1.415514 & 2.0369 & 0.1698 \\
\hline DLOG(Y(-2)) & 0.441165 & 1.496673 & 2.0369 & 0.1475 \\
\hline DLOG(Y(-3)) & 0.154584 & 0.987619 & 2.0369 & 0.3332 \\
\hline DLOG(X1) & 0.253363 & 2.086906 & 2.0369 & 0.0477 \\
\hline DLOG(X2) & 0.129267 & 1.076155 & 2.0369 & 0.2926 \\
\hline DLOG(X3) & 0.906897 & 2.110872 & 2.0369 & 0.0077 \\
\hline ECM(-1) & -0.025000 & -3.754431 & 2.0369 & 0.0010 \\
\hline $\mathrm{R}^{2}=0.6947$ & $\mathrm{DW}=1.6512$ & F-stat=6.8286 & F-table=3.36 & \\
\hline
\end{tabular}

Source: Researcher's Computation from (E- view 9.0) Result in the Appendix II

The parsimonious error correction model (ECM) in Table 6 above indicated that the dynamic model is a good fit as depicted by the $\mathrm{R}^{2}$. This is so because the variation in the dependent variable account for 69 percent of the total variation in the explanatory variables in the model. The Durbin Watson (DW) value of 1.65 , which is not too far from the bench mark of 2.0, suggests a lesser level of autocorrelation. Thus, the model is good for policy formulation and implementation.

Meanwhile, an important factor to be noticed in Table 6 is the coefficient of the parameter of error correction mechanism (-0.02500). Thus, the coefficient of ECM has the hypothesized negative sign and is statistically significant at 5\% level.This showed that about 25percent disequilibria in the agricultural production output in the previous year were corrected for in the current year. It therefore, follows that the ECM could rightly correct any deviations from short run to long-run equilibrium relationship of the dependent and the explanatory variables.

Furthermore, the coefficients of current forms of government funding in agriculture (X1) is positively signed and statistically significant at 5 percent level. This means that government funding in agriculture contributed $25.3363 \%$ to increase the output of the agricultural production and hence the Nigerian economy during the period of study. This result is in line with the finding of Imahe1 and Alabi (2005) that examined the determinants of agricultural productivity in Nigeria and posited that government capital expenditure contributed positively and significantly to the output of agricultural production in Nigeria.

Also, the coefficient of current forms of agricultural credit $\left(\mathrm{X}_{2}\right)$ is positively signed but statistically not significant at 5 percent level. This means that a percentage increase in agricultural credit will boost agricultural production output by $12.9267 \%$. But, agricultural credit does not impacted on the output of the agricultural output. The fact that agricultural credit does not impact onagricultural production output means that agricultural credit is not the only determinant of agricultural output in Nigeria during the period of study. This result supports the finding of Kareem, Bakare, Raheem, Ologunla, Alawode and Ademoyewa (2013) in their analysis of the determinants of agricultural sector output in Nigeria and affirms that credit to agricultural sector contributed positively to agricultural sector output in Nigeria.

The analysis equally showed that the coefficient of current forms of climate change $\left(\mathrm{X}_{3}\right)$ is positively and significantly related with agricultural production output in Nigeria during the period of study. Thus, a percentage increase in climate change will increase the output of agricultural production by $90.68 \%$ in Nigeria during the period of study. Meanwhile, the results alsoa significant relationship between climate change and agricultural production output in Nigeria during the period of study. This result supports the finding of Hoffmann (2013) who affirmed that climate change and agriculture are interrelated processes and can affects agriculture negatively/positively. 


\section{CONCLUSION AND RECOMMENDATIONS}

The study examined the determinants of agricultural production in the Nigerian economy. Thus, the study affirms that agriculture is the key routes to Nigeria's prosperity in the new millennium if the government(s) and private individual investors gave the sector the needed attention it demands. This is because Agricultural development will provide the economy with the opportunity to diversify the productive and export base of its economy.

The study was carried out based on secondary data collected through the CBN statistical bulletin and with the use of econometrics methods of unit root test, co-integration and ECM test. The findings from the study showed that agricultural funding, climate change and agricultural credit are key determinants of agricultural output in Nigeria.

The paper concludes that if the aforementioned are taking into consideration, Nigeria agricultural sector will soon become a sector capable of ensuring self-sufficiency in raw materials for industrialization, being source of employment and a major contributor to foreign exchange earnings in the country. Based on the findings from the study, the study recommends the following;Government should provide adequate fund to the agricultural sector in the yearly budget in order to meet the basic needs of the rural farmers vis-a-vis the provision of infrastructural facilities.Government should provide loan or credit to the agricultural sector via the rural farmers through community banks. Also, strategies will need to differ between favourable and unfavourable agro climatic zones with proper conditions; increased productivity can be expected in the favourable zones. Expectations for cropping intensification are more modest for the agro-climatically unfavourable and fragile zones where attention will need to be paid to alternative income sources off-farm. This will promote food production in the agro-climatically unfavourable zones and increase effective demand for farm products from favourable zones.

\section{REFERENCES}

[1] Adeyemo, A.O. (2015).Analyses of the Determinants of Palm Oil Production in Nigeria (1971-2010). Greener Journal of Agricultural Sciences, 5 (4), 110-117.

[2] Ahuja, H.L. (2012). Modern Economics; Analytical Studies of Environment and Economic Development. New Delhi: S. Chad and Company PVT Ltd.

[3] Anigbogu, T. U., Abosi, O. E. \&Okoli, I. M. (2015). Socio-Economic Factors Influencing Agricultural Production among Cooperative Farmers in Anambra State, Nigeria. International Journal of Academic Research in Economics and Management Sciences, 4(3).

[4] Ahmad, K. \&Heng, A.C.T. (2012). Determinants of Agriculture Growth in Pakistan. International Research Journal of Finance and Economic. (95), 163-172.

[5] CBN (2013). Annual Report Economic Report, $31^{\text {st }}$ December, 2013.

[6] Dickey, D. A. \& Fuller, W. A. (1979). Distribution of Estimators for Autoregressive Time Series and Unit Roots. Journal of American Statistical Association, 74(2), 427-31

[7] Hoffmann, U. (2013). Agriculture - A Key Driver and a Major Victim of Global Warming. Lead Article, Chapter 1, 3- 5

[8] Imahel, O. J. \&Alabi, R.A. (2005). The Determinants of Agricultural Productivity in Nigeria. Journal of Food, Agriculture \& Environment, $3(2), 269-274$.

[9] Ikeh, G. (2013). Nigerian Economy: Agricultural Sector to the Rescue. The Business Eye, Nigeria's Investigative Business Journal, 7

[10] Johansen, S. (1988).Statistical Analysis of Co-integrating Vectors. Journal of Economic Dynamics and Control, 12, 231 - 54.

[11] Johansen, S. (1998). Statistical Analysis and Co-integrating Vectors. Journal of Economic Dynamics and Control, 12(2-3), 231-254.

[12] Johansen, S. \&Juselius, K., (1990).Maximum Likelihood Estimation and Inference on Cointegration: with Application to Demand for Money. Oxford Bulletin of Economics and Statistics, 52, 169-210.

[13] Kareem, R.O, Bakare, H.A, Raheem, K.A, Ologunla, S.E, Alawode, O.O. \&Ademoyewa, G.R. (2013). Analysis of factors influencing agricultural output in Nigeria: Macro-economic perspectives. American Journal of Business, Economics and Management, 1(1), 9-15 
[14] Nworgu, F.C. (2006). Prospects and Pitfalls of Agricultural Production in Nigeria. Ibadan: Blessed Publication.

[15] Obi, K.O. \&Obayori, J.B. (2016).Dynamic Effect of Government Spending on Agricultural Output in Nigeria. The International Journal of Social Sciences and Humanities Invention Volume 3 (2), 1880-1886

[16] Odhiambo, W., Nyangito, H.O. \&Nzuma, J. (2004) Sources and Determinants of Agricultural Growth and Productivity in Kenya from 1965-2001. Kenya Institute for Public Policy Research Analysis.Discussion Paper, 34, Nairobi.

[17] Oluwatoyese, O.P. \&Applanaidu, S.D.A/P. (2014).Effect of Agricultural Sector Determinants on Economic Growth in Nigeria. Proceedings of Book of ICETSR. Malaysia: PAK Publishing Group.

[18] Oyekale, A.S. (2007). Determinants of Agricultural Land Expansion in Nigeria: An Application of Error Correction Modeling. Journal of Central European Agriculture. 8(3), 301-310.

[19] Polycarp, I.M. \&Jirgi, A.J. (2011). Agricultural Finance Policies and Strategies in Nigeria: Issues and Implications for Increased Outreach. A Paper Presented at the 2011 Annual Conference of the Nigerian Economic Society

[20] Udah, S.C \&Nwachukwu, I.N. (2015). Determinants of Agricultural GDP Growth in Nigeria. International Journal of Agricultural Research and Review. 3(3), 184-190.

[21] Udah, S.C.,Nwachukwu, I.N., Nwosu, A.C., Mbanasor, J.A. \&Akpan, S.B. (2015). Determinants of Agricultural Export Growth in Nigeria. International Journal of Agricultural Forestry and Fisheries. 3(3), 105-109.

[22] Ugwumba, C.O.A. \&Omojola, J.T. (2012). Socio-Economic Determinants and Profitability of Yam Production in Ipao-Ekiti, Nigeria. Journal of Science and Multidisciplinary Research 4(12).

[23] Ukeje, E.U. (2010). Production in the Agricultural Sector. Assistant Director, Research Department, Central Bank of Nigeria. 